\title{
The 'maximum growth/optimal food condition' hypothesis: a test for 0-group plaice Pleuronectes platessa in the Dutch Wadden Sea
}

\author{
Henk W. van der Veer, Johannes IJ. Witte \\ Netherlands Institute for Sea Research (NIOZ), PO Box 59, 1790 AB Den Burg Texel, The Netherlands
}

\begin{abstract}
A test of the 'maximum growth/optimal food condition' (MG/OFC) hypothesis is described for 0-group plaice Pleuronectes platessa L. in the western Dutch Wadden Sea. The MG/OFC hypothesis assumes optimal food conditions (i.e. no competition for superfluous food and hence no negative density-dependent growth) and consequently a maximum growth rate only determined by prevailing water temperature conditions. Growth of 0-group plaice subpopulations was determined for a number of areas differing in food abundance and composition (benthic biomass of potential food items) and density of 0 -group plaice in both the intertidal and the sublittoral. Growth showed a positive relationship with food abundance, in both the intertidal and the sublittoral, falsifying the MG/OFC hypothesis. At similar food abundance, growth in the intertidal was always higher than in the sublittoral due to the presence of the lugworm Arenicola marina in the intertidal only. In the intertidal, growth was positively related to density of $A$. marina. The assumption of the MG/OFC hypothesis of no negative densitydependent growth was confirmed both in the intertidal and in the sublittoral, although it did not resul.t in maximum growth rate for 0 -group plaice everywhere in the field. Differences in growth rate therefore do not necessarily reflect competition for food and density-dependent growth, but they might reflect differences in food composition and availability (searching and handling time)
\end{abstract}

\section{INTRODUCTION}

Plaice Pleuronectes platessa L. is a species characterized by a 'concentration' of juveniles in restricted socalled nursery areas (e.g. Zijlstra 1972, Beverton 1984). It was thought that such a 'concentration' of individuals might result in an intraspecific competition for food. The first observations on growth of juvenile plaice in a Scottish bay, Loch Ewe, supported this view. Different growth rates were found over years, which suggested food-limited growth (Edwards \& Steele 1968, Steele \& Edwards 1970). However, subsequent research in the western part of the Dutch Wadden Sea revealed that fluctuations in growth over the years could be explained by differences in water temperature (Zijlstra et al. 1982). Estimates of the food requirements of 0-group plaice in the Wadden Sea supported this view. Food consumption of the population was of the order of a few $\mathrm{g} \mathrm{m}^{-2}$, compared with a 10 -fold higher production and biomass of the macrozoobenthos
(Kuipers 1977). A re-analysis of the data of Steele \& Edwards (1970) showed that in Loch Ewe also, the observed differences in growth could be explained by variation in water temperature (Zijlstra et al. 1982). Preliminary observations in a subtropical estuary by Reichert \& van der Veer (1991) also supported this view.

These observations resulted in the theory that food was not limiting growth and that the variability in growth of 0 -group plaice between years and between areas was not caused by intraspecific density-dependent processes but only by differences in prevailing water temperatures (Zijlstra et al. 1982). More recent studies on 0-group plaice in the western Dutch Wadden Sea (van der Veer 1986) and in Swedish bays (van der Veer et al. 1990), and on I-group plaice (Bergman et al. 1988) and 0-group flounder (van der Veer et al. 1991) in the western Dutch Wadden Sea supported this theory in all cases.

However, growth analyses of 0 -group plaice by means of a completely different method, otolith- 
microstructure analysis, in the German Wadden Sea suggested that food conditions and food competition could affect growth rates in these areas (Berghahn 1987). Comparisons between areas and between years revealed different growth rates, which could indicate food limitation (Karakiri et al. 1989). Karakiri et al. (1991) applied the otolith-microstructure analysis to study growth in different areas of the Dutch Wadden Sea. Although growth rates in the various areas differed, they could be explained by differences in period of growth. No negative density-dependent growth was found. Back-calculation of somatic growth of juvenile plaice by otoliths over the period 1930 to 1985 also showed different growth over the years. An increase in growth was observed from the 1950 s onwards (Rijnsdorp \& van Leeuwen 1992), which was suggested to be related to an increase in the availability of food in the coastal zone over this period.

So far, the contradicting results between otolith readings on the one hand and field studies on length growth on the other cannot be explained. However, based on the observations described above, the following model (or theory) is postulated: individual growth of juvenile flatfish is determined by prevailing water temperature. Flatfish are demersal and after settling and metamorphosis they live mainly on benthic epiand infauna. These food sources are fairly constant and continuously available. Food is thought to be present in excess, and therefore never growth limiting. As a consequence there will be no competition for food, neither intra-nor interspecific. The absence of intraspecific competition means that there will be no density-dependent growth. In this respect, maximum growth is a growth rate only determined by prevailing temperatures and similar to the maximum growth rate found under experimental laboratory conditions of food excess (Zijlstra et al. 1982, van der Veer 1986, van der Veer et al. 1990, 1991, Karakiri et al. 1991). The situation in which maximum growth occurs has been called optimal food conditions, which is actually an infelicitous expression (Zijlstra et al. 1982, van der Veer 1986, van der Veer et al. 1990). It really means a situation where growth is not (negatively) densitydependent. This theory was introduced by Karakiri et al. (1991) as the 'maximum growth/optimal food condition' (MG/OFC) hypothesis, although it is actually not a hypothesis but a theory.

In none of the growth studies have all the important factors, such as density, food abundance and availability and water temperature, been determined simultaneously. In this paper, the results of such a study carried out on different subpopulations of 0 group plaice in the western Dutch Wadden Sea are described. A detailed analysis of the factors that determine the growth of 0 -group plaice in the Wadden
Sea is presented and the following hypotheses are tested: (1) growth is not food limited and is only dependent on prevailing water temperature, and (2) there is no intraspecific competition for food, which means no negative density-dependent growth

\section{MATERIAL AND METHODS}

Sampling stations. A total of 19 stations were selected (Fig. 1), according to the following criteria: (1) the sampling programme should incorporate stations in the different types of area, the intertidal, the sublittoral and the tidal channels. The intertidal is defined as the area with drained tidal flats at low-low-water spring (LLWS). Sublittoral areas are areas between LLWS and LLWS $-5 \mathrm{~m}$. Tidal channels are areas deeper than $5 \mathrm{~m}$ below LLWS; (2) the stations should cover a wide range of benthic biomass values; (3) the exchange of individuals between the various sampling sites must be excluded as much as possible; (4) the bottom structure must allow fishing with beam trawls, which means an exclusion of extremely silty areas.

Benthic survey. A benthic survey was carried out at each sampling station in September 1986. Between 5 and 15 samples of at least $15 \mathrm{~cm}$ depth were collected with a $0.06 \mathrm{~m}^{2}$ box core. Out of each sample, 5 small cores $\left(4.5 \mathrm{~cm}^{2}\right.$ each) of $10 \mathrm{~cm}$ depth were taken to

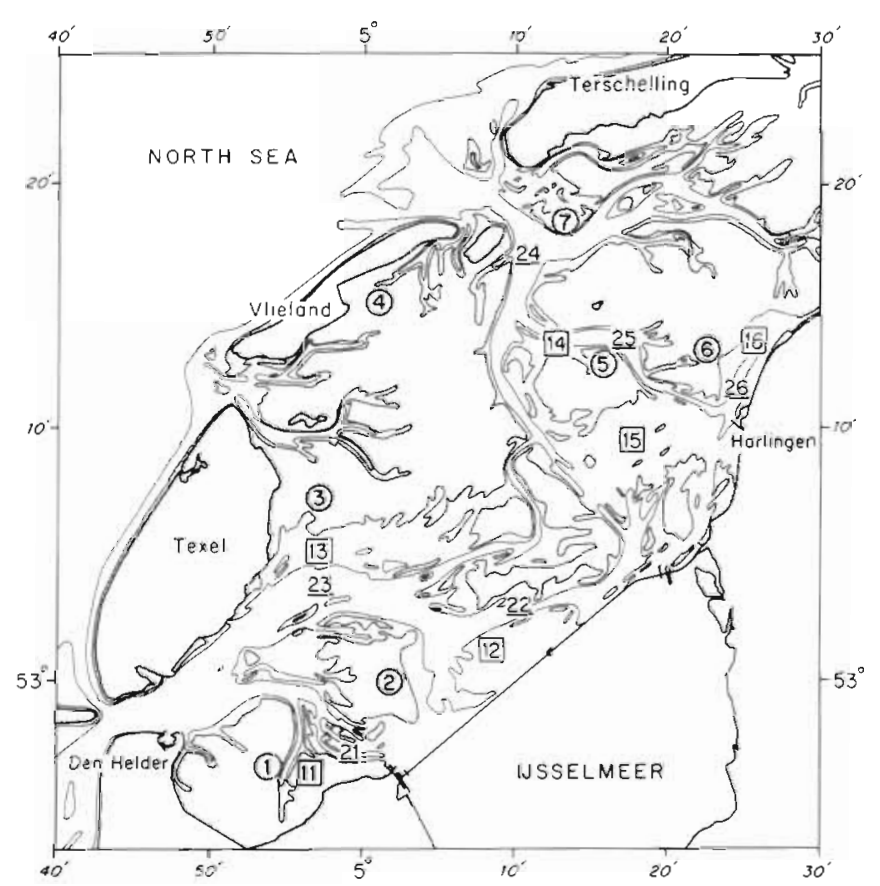

Fig. 1 Location of sampling stations in the western Dutch Wadden Sea. Stns 1 to 7 : intertidal; Stns 11 to 16 : sublittoral; Stns 21 to 26: tidal channel. Station number refers to code in Table 1 
analyse sediment structure. The remainder of the samples was used for analyses of the macrobenthic community.

Grain-size distribution of the sediment was determined by drying a sediment sample at $60^{\circ} \mathrm{C}$ for $2 \mathrm{~d}$. Afterwards, the sediment was sieved over a number of graded sieves. After weighing each fraction, the median grain size was determined. Silt content was estimated by decanting the silt from a subsample. After filtering over a Whatman $2 \mathrm{~V}$ filter and drying at $60^{\circ} \mathrm{C}$ for $2 \mathrm{~d}$, the weight of the silt fraction was measured and expressed as percentage of the total dry weight of the sediment. Mean values were determined for each sampling station.

Macrobenthic animals were collected by sieving the sediment through a $1 \mathrm{~mm}$ sieve. They were preserved in a $4 \%$ formalin-seawater solution and sorted out in the laboratory into species and if possible into different year classes. Ash-free dry weights (AFDW) were determined for all animals or of subsamples by drying at $60^{\circ} \mathrm{C}$ for $2 \mathrm{~d}$ and subsequent burning at $560^{\circ} \mathrm{C}$ for $2 \mathrm{~h}$. The weight loss at $560^{\circ} \mathrm{C}$ was considered to represent AFDW. All numbers and biomass values were converted into numbers or $\mathrm{g}$ AFDW per $\mathrm{m}^{2}$ (nos. $\mathrm{m}^{-2}$ and $\mathrm{g}$ AFDW $\mathrm{m}^{-2}$ ). For each station the arithmetic mean value was computed. For the intertidal stations, comparative data-sets of macrozoobenthic biomass were available for 1971 and 1977 (Beukema 1989).

0-group plaice. Sampling was carried out for $1 \mathrm{wk}$ every month in 1986, alternately in the Marsdiep basin and the Vlie basin. Thus, each station was visited every other month. Sampling was carried out for $3 \mathrm{~h}$ around high water during daytime following Kuipers $(1973,1977)$, since during this period the migrating part of the plaice population is distributed randomly over the tidal flats, and consequently the migrating intertidal and the resident sublittoral populations will be split up. In the intertidal, fishing was done from a rubber dinghy powered by a $25 \mathrm{hp}$ outboard motor using a $2 \mathrm{~m}$ beam trawl with 1 tickler chain and a $5 \times 5 \mathrm{~mm}$ mesh size knotless nylon net. The distance covered by the hauls was registered by a meter wheel fitted to the frame. At each location 2 or 3 hauls of about $300 \mathrm{~m}$ were made, covering a total area of at least $1200 \mathrm{~m}^{2}$. In the sublittoral and deeper gullies, fishing was done by RV 'Navicula' using a heavier $3 \mathrm{~m}$ beam trawl with 1 tickler chain and a $1 \times 1 \mathrm{~cm}$ mesh size. For a more detailed description see Bergman et al. (1989). At each station, 1 to 3 hauls were made of at least $600 \mathrm{~m}$, covering at least $1800 \mathrm{~m}^{2}$.

After sorting within a few hours, the plaice were measured in $0.5 \mathrm{~cm}$ total length classes. In case of doubt, the age was checked by means of otolith reading. All numbers caught were corrected for net efficiency and converted to numbers per $1000 \mathrm{~m}^{2}$ (nos. $1000 \mathrm{~m}^{-2}$ ). For the $2 \mathrm{~m}$ beam trawl the efficiency according to Kuipers (1975) and Dapper (1978) was used and for the $3 \mathrm{~m}$ beam trawl the efficiency according to Bergman et al. (1989) was applied. For each station arithmetic-mean abundance and length were estimated, since size-frequency distributions were normal. Throughout the year, stomach content of samples of freshly caught 0 -group plaice of all locations was analysed to determine potential food items of plaice. Stomach composition was determined at species level and the AFDW of each food item was estimated.

All statistical analyses were done with SYSTAT (Wilkinson 1989).

\section{RESULTS}

\section{Benthic survey}

Table 1 lists the main sediment characteristics together with the mean biomass of the macrozoobenthos of the various sampling stations. Macrofauna biomass values showed only a weak relationship with silt content (Spearman rank correlation test, $r_{\mathrm{s}}=0.37$, $\mathrm{n}=19$ ). A comparison with the intertidal macrozoobenthos surveys of 1971 and 1977 (Beukema 1989) showed that the patterns in abundance were significantly positively related with each other (Table 2), $r_{\mathrm{s}}=0.54$ (1971 vs 1986) and $r_{\mathrm{s}}=0.77$ (1977 vs 1986). Variations in abundance over the years were mainly due to fluctuations in the abundance of the blue mussel Mytilus edulis.

Fig. 2 shows the prey items of 0 -group plaice in the intertidal and in the sublittoral during June to September based on percentage of stomachs containing 1 or more individuals of a species. The number of plaice found in the tidal channels was too low to permit an analysis in this group. Within both the intertidal and the sublittoral, plaice stomach content did not differ between stations. Food composition was for the most part similar in the intertidal and the sublittoral. Of the 0 -group, $60 \%$ had eaten 1 or more polychaetes and siphon tips of bivalves. The only difference was the absence of tail tips of the lugworm Arenicola marina in stomachs in the sublittoral. In the intertidal, tail tips were found in $10 \%$ of stomachs. Almost all other macrozoobenthic species were found in low frequencies, but the blue mussel Mytilus edulis and the mud snail Hydrobia ulvae were completely absent. Although only a proportion of the total biomass is available for plaice, differences in food abundance between areas can be indicated by total biomass values minus those of blue mussel and of the mud snail (Table 1). 
Table 1. Sediment characteristics and biomass values of macrofauna and of food abundance of 0-goup plaice, estimated as total biomass minus that of the blue mussel and the mud snail

\begin{tabular}{|c|c|c|c|c|c|}
\hline Stn no. & Stn & $\begin{array}{l}\text { Median grain } \\
\text { size }(\mu \mathrm{m})\end{array}$ & $\begin{array}{c}\text { Silt content } \\
(\%)\end{array}$ & $\begin{array}{l}\text { Macrofauna } \\
\left(\mathrm{g} \text { AFDW m }{ }^{-2}\right)\end{array}$ & $\begin{array}{l}\text { Food abundance } \\
\left(\mathrm{g} \text { AFDW } \mathrm{m}^{-2}\right)\end{array}$ \\
\hline \multicolumn{6}{|c|}{ Intertidal } \\
\hline 1 & Balgzand & 149 & 3 & 25.0 & 18.7 \\
\hline 2 & Lutjeswaard & 196 & 2 & 22.3 & 10.6 \\
\hline 3 & Wadplaat & 179 & 2 & 113 & 6.6 \\
\hline 4 & Vlie & 165 & 1 & 48.7 & 48.2 \\
\hline 5 & H.Tjaars & 197 & 1 & 36.5 & 17.9 \\
\hline 6 & Ballastplaat & 135 & 6 & 56.1 & 32.8 \\
\hline 7 & Robbenplaat & 188 & 0 & 4.9 & 4.9 \\
\hline \multicolumn{6}{|c|}{ Sublittoral } \\
\hline 11 & Breehorn & 142 & 11 & 73.5 & 58.4 \\
\hline 12 & Vlieter & 166 & 2 & 68.4 & 14.9 \\
\hline 13 & Wadden & 210 & 2 & 28.5 & 7.9 \\
\hline 14 & Pannenplaat & 155 & 3 & 3.5 & 3.5 \\
\hline 15 & Pollen & 158 & 2 & 54.6 & 19.7 \\
\hline 16 & Kimstergat & 184 & 2 & 26.0 & 25.0 \\
\hline \multicolumn{6}{|c|}{ Tidal channel } \\
\hline 21 & Wierbalg & 167 & 1 & 23.2 & 23.2 \\
\hline 22 & Doove Balg & 229 & 2 & 1.5 .9 & 15.9 \\
\hline 23 & Texelstroom & 242 & 0 & 1.7 & 1.7 \\
\hline 24 & Vliestroom & 270 & 0 & 0.2 & 0.2 \\
\hline 25 & Blauwe Slenk & 192 & 1 & 8.9 & 8.9 \\
\hline 26 & Kimstergat & 205 & 2 & 35.4 & 31.9 \\
\hline
\end{tabular}

\section{0-group plaice}

The seasonal course of abundance of 0-group plaice at the various stations is presented in Fig. 3. The first o-group plaice were found between February and April. After May, densities decreased especially in the intertidal. In autumn, hardly any 0-group were found in the intertidal at high water. In the sublittoral, numbers also decreased after settlement but increased again in autumn. Lowest densities were found in the tidal channels until autumn. From autumn onwards, densities increased.

Fig. 4 shows the mean lengths of 0-group plaice at the various stations. At all stations, mean length increased until early October. Mean length increase at the intertidal stations was higher than in the sublittoral, resulting in a size range of 80 to $100 \mathrm{~mm}$ at the

Table 2. Interannual comparison of macrobenthic biomass ( $g$ AFDW $\mathrm{m}^{-2}$ ) values at the 6 repeatedly sampled intertidal stations. Data for 1971 and 1977 from Beukema (1989)

\begin{tabular}{|clrrr|}
\hline Stn no. & Stn & 1971 & 1977 & 1986 \\
\hline 1 & Balgzand & 22.4 & 34.0 & 25.0 \\
2 & Lutjeswaard & 13.7 & 14.3 & 22.3 \\
3 & Wadplaat & 18.9 & 8.4 & 11.3 \\
4 & Vlie & 72.4 & 100.4 & 48.7 \\
5 & H.Tjaars & 6.3 & 9.0 & 36.5 \\
6 & Ballastplaat & 31.4 & 37.8 & 56.1 \\
\hline
\end{tabular}

end of the growing season in the intertidal, compared with 60 to $80 \mathrm{~mm}$ in the sublittoral. Mean length in the tidal channel showed a range of between 70 and $100 \mathrm{~mm}$ at the beginning of October.

\section{Growth analysis}

Since the various stations were not sampled simultaneously and migration movements occurred from

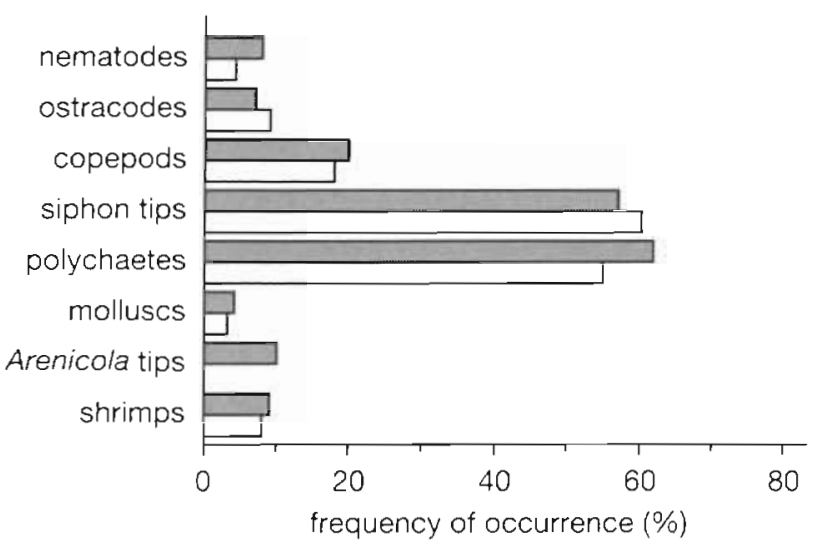

Fig. 2. Pleuronectes platessa. Mean percentage $(\%)$ of 0 group plaice containing 1 or more prey items of different macrozoobenthic species in the stomach at the various sampling stations in the western Wadden Sea in the intertidal (shaded bars) and the sublittoral (open bars) 


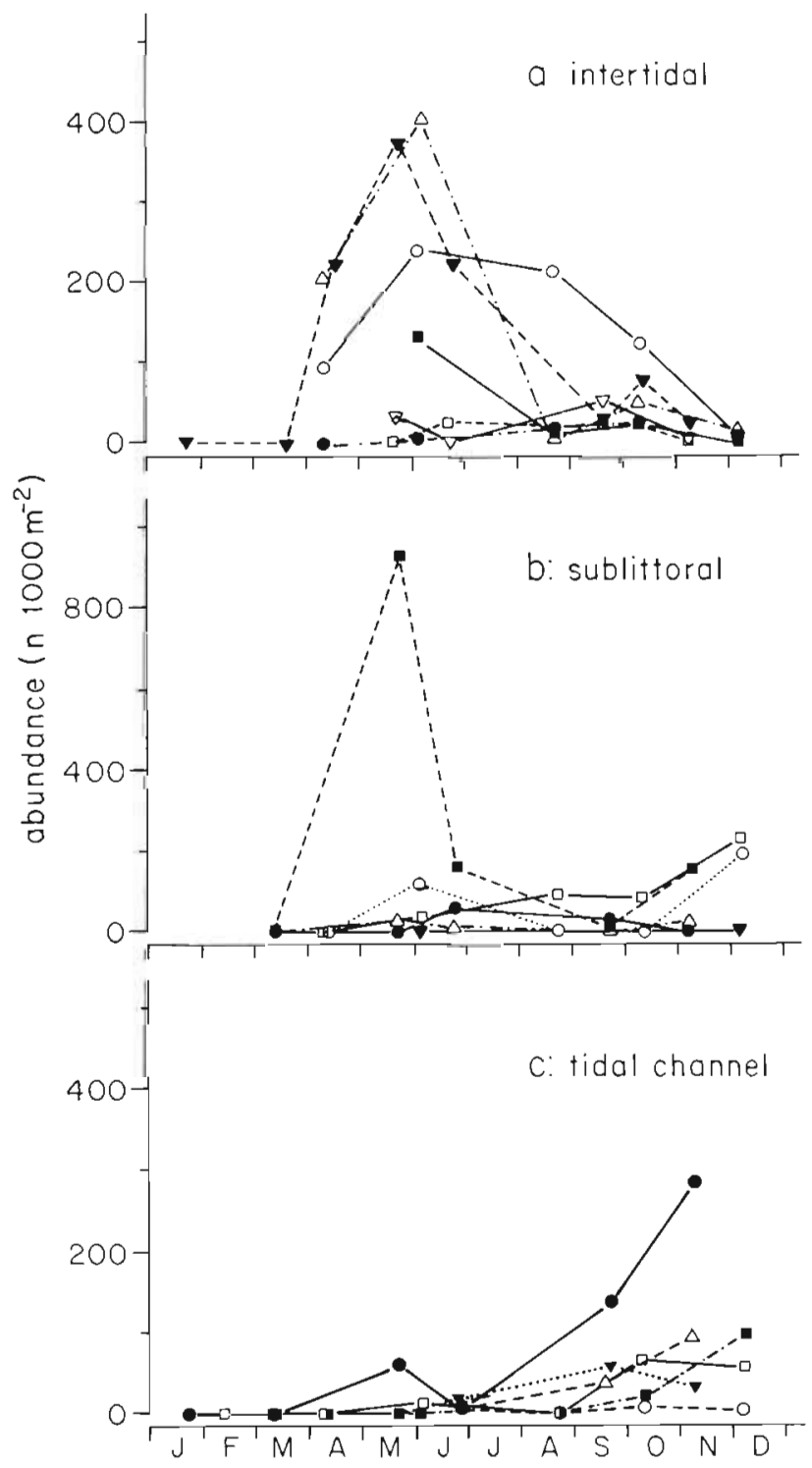

Fig. 3. Pleuronectes platessa. Seasonal abundance patterns of 0 -group plaice (nos. $1000 \mathrm{~m}^{-2}$ ) at the various stations in the western Wadden Sea. (a) Stn $1=\nabla ; 2=\nabla ; 3=\square ; 4=O_{;} 5=\bullet$ $6=\Delta ; 7=\mathbf{\square}$; (b) $11=\mathbf{\square} ; 12=\bullet ; 13=\Delta_{i} 14=\mathbf{\nabla} ; 15=0 ; 16=\square$; (c) $21=\bullet ; 22=\nabla ; 23=\Delta ; 24=0 ; 25=\square ; 26=\square$

October onwards, the comparison of growth in 0 -group plaice was restricted to the period 1 June to 1 October. During this period, increase in mean length was almost linear, and therefore growth was estimated by a linear regression model. Table 3 shows the growth estimates for the various areas together with the standard error in the estimate and the correlation coefficient. The standard errors of the various estimates varied between 1.8 and $9.4 \mathrm{~mm}$. Only the stations in the intertidal and the sublittoral were analysed, since densities in the tidal channel were too low and too variable. Growth differed considerably between stations, in both the intertidal ( 42 to $52 \mathrm{~mm}$ ) and the sublittoral (30 to $44 \mathrm{~mm}$ ). On average, growth in the intertidal was faster than in the sublittoral (49.7 vs $35.2 \mathrm{~mm}$ ).

For the growth analysis, 4 factors were considered: water temperature, food abundance, plaice density and type of area (intertidal versus sublittoral). A detailed analysis of differences in water temperature between stations was not possible since the frequency of measurements was too low. There was no difference in water temperature at high water
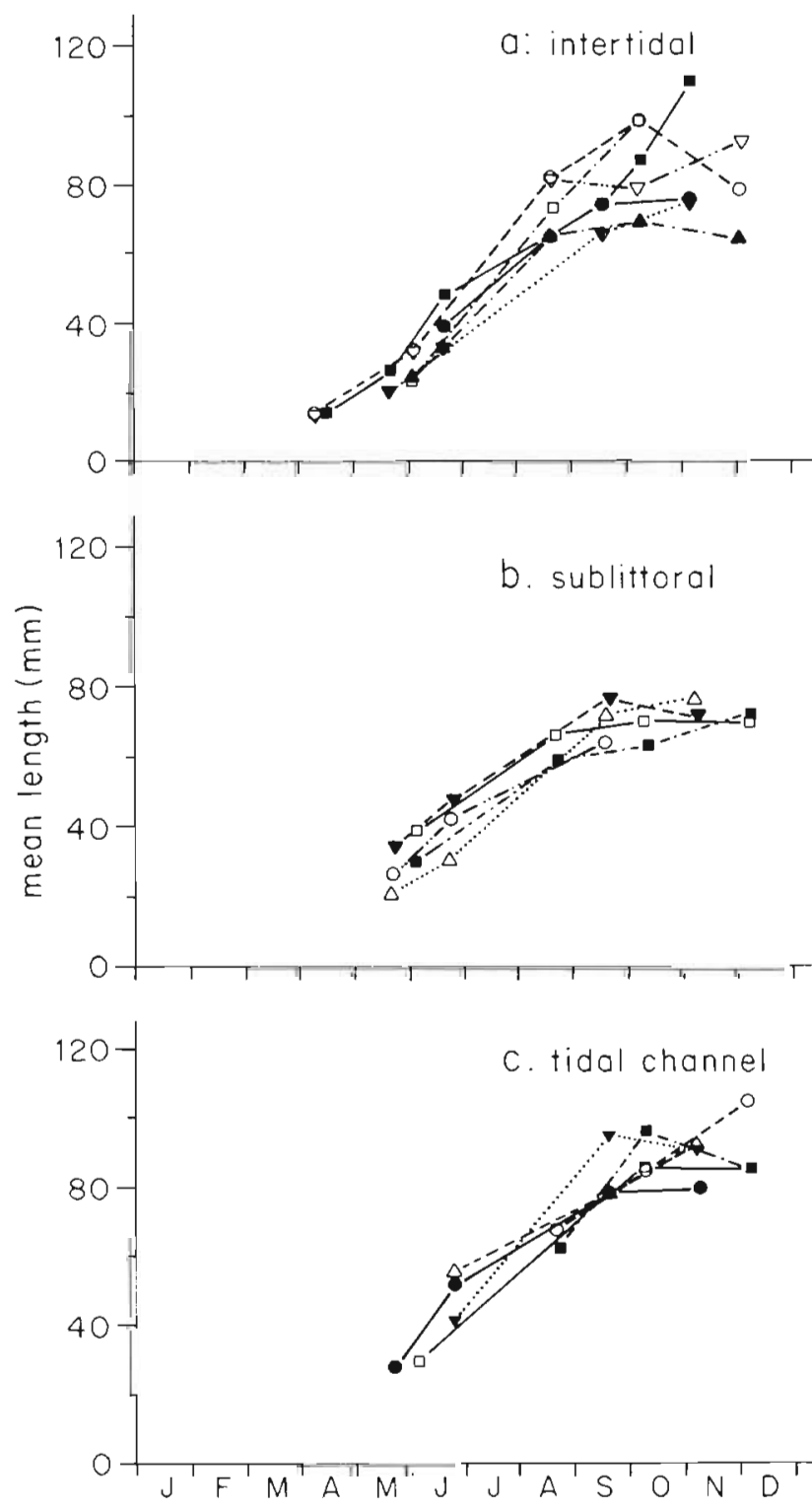

Fig. 4. Pleuronectes platessa. Mean length of 0-group plaice at the various stations in the western Wadden Sea. (a) $\operatorname{Stn} 1=\square ; 2=\nabla ; 3=\bullet ; 4=0 ; 5=\square ; 6=\nabla ; 7=\mathbf{\Delta}_{;}$(b) $11=\nabla$; $12=0 ; 13=\Delta ; 15=\square ; 16=\square ;$ (c) $21=\bullet ; 22=\boldsymbol{\nabla} ; 23=\Delta$; $24=0 ; 25=\mathbf{\square} ; 26=\square$ 
Table 3. Growth ( $\mathrm{mm}$ ) of 0 -group plaice in the intertidal and sublittoral between 1 June and 1 October, estimated by means of linear regression, together with standard error (SE), number of observations $(n)$ and explained variance $\left(r^{2}\right)$

\begin{tabular}{|lcccc|}
\hline Stn & $\begin{array}{c}\text { Growth } \\
(\mathrm{mm})\end{array}$ & $\mathrm{SE}$ & $\mathrm{n}$ & $\mathrm{r}^{2}$ \\
\hline Intertidal & & & & \\
$\quad$ Balgzand & 51 & 5.9 & 4 & 0.95 \\
Wadplaat & 45 & 7.8 & 3 & 0.79 \\
Lutjeswaard & 44 & 5.5 & 3 & 0.96 \\
Vlie & 63 & 9.4 & 3 & 0.95 \\
Robben & 42 & 8.9 & 3 & 0.82 \\
H.Tjaars & 51 & 6.6 & 3 & 0.99 \\
Ballastplaat & 52 & 9.4 & 3 & 0.95 \\
Sublittoral & & & & \\
Breehorn & 44 & 1.8 & 3 & 0.99 \\
Wadden & 32 & 6.4 & 4 & 0.94 \\
Vlieter & 39 & 6.2 & 3 & 0.94 \\
Richel & & & & \\
Pollen & 31 & 5.8 & 4 & 0.87 \\
Kimstergat & 30 & 8.0 & 3 & 0.87 \\
& & & & \\
\hline
\end{tabular}

between intertidal and the sublittoral (Fig. 5). Some variability between stations could be observed, but no trend was found (Fig. 6). Therefore, water temperature was not incorporated in the analysis of growth. For both the intertidal and the sublittoral areas, growth was not negatively density-dependent, but in contrast appeared to be positively related with plaice density (Fig. 7) at least in the intertidal $\left(r_{\mathrm{s}}=\right.$ $0.45, \mathrm{n}=7$ ). For both areas growth was positively related with food abundance (Fig. 8). In the intertidal this relationship was significant $\left(r_{s}=0.99, \mathrm{n}=7\right)$, in the sublittoral, the number of observations was too low $\left(r_{\mathrm{s}}=0.30, \mathrm{n}=5\right)$.

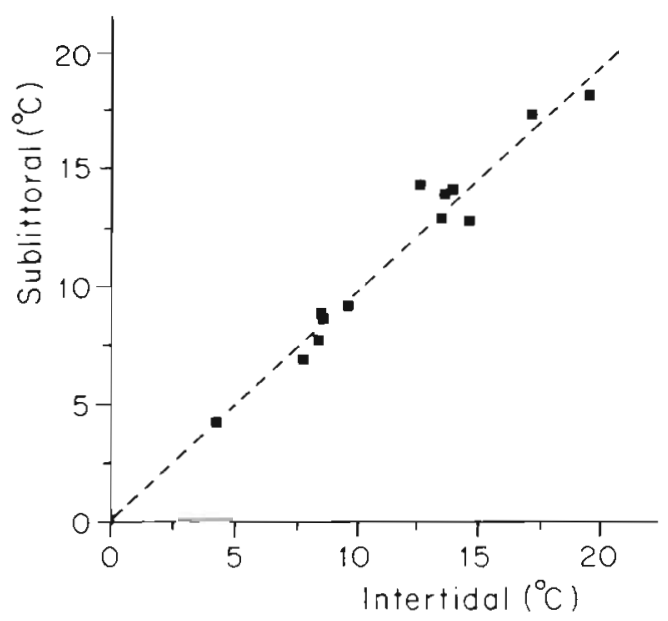

Fig 5. Relationship between water temperature $\left({ }^{\circ} \mathrm{C}\right)$ at high water in the intertidal and the adjacent sublittoral in the western Wadden Sea in 1988; all observations combined

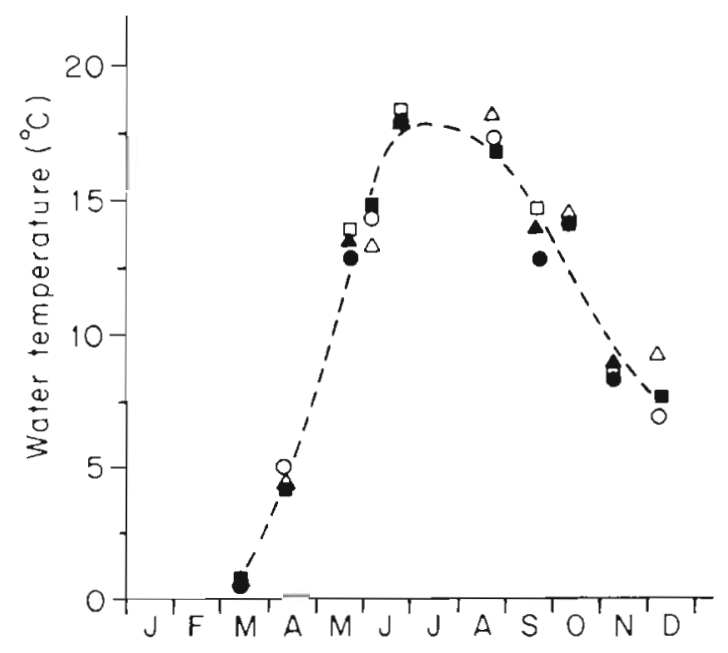

Fig. 6. Water temperature $\left({ }^{\circ} \mathrm{C}\right)$ at high water in the intertidal at the various stations in the western Wadden Sea in 1988. $\operatorname{Stn} 1=\bullet ; 2=\square ; 3=\Delta ; 4=\Delta ; 5=\mathbf{a} ; 6=0$

Growth was analysed by means of a multiple linear regression model, in which food abundance, plaice density and type of area (intertidal versus sublittoral) were considered as independent factors (Table 4). A significant difference was found between the intertidal and the sublittoral. Furthermore, growth was positively related with food abundance. A negative relationship with plaice density was found, but it was not significant. This contradicted the positive relationship between plaice density and growth described in Fig. 7 This means that since plaice density and food abundance were also related, Fig. 7 in reality reflects the underlying relationship between food abundance and growth.

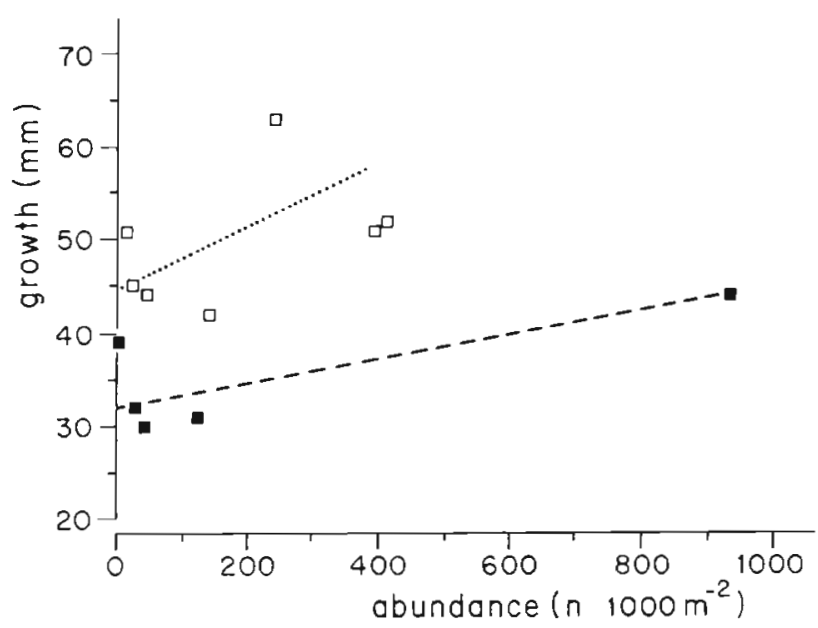

Fig. 7. Pleuronectes platessa. Relationship between growth of 0-group plaice (mm) and density of 0-group plaice (nos, $1000 \mathrm{~m}^{-2}$ ) during the period 1 June to 1 October in the western Wadden Sea at the intertidal ( $\square$ ) and sublittoral (a) stations 


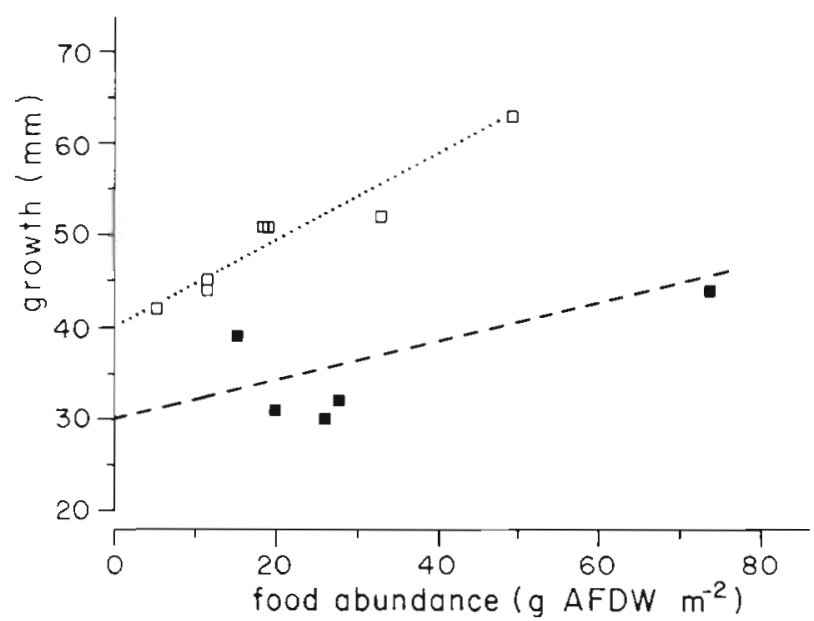

Fig. 8. Pleuronectes platessa. Relationship between growth of 0 -group plaice $(\mathrm{mm})$ and food abundance (g AFDW $\mathrm{m}^{-2}$ ) during the growth period (1 June to 1 October) in the western Wadden Sea in the intertidal $(\square)$ and sublittoral (

\section{DISCUSSION}

\section{Test conditions}

The key aspect of the test of the MG/OFC hypothesis is a comparison between growth of 0 -group plaice (sub)populations in different areas. A basic condition is that the observed increase in mean length over the season reflects the growth of that population. Thus, mixing between (sub)populations must be negligible.

The sampling programme was carried out at high water. At that time, the intertidal and sublittoral plaice populations are spatially separated (Kuipers 1977). Moreover, sampling in the sublittoral always occurred at least $1 \mathrm{~km}$ away from the tidal flats. Kuipers (1973) found that intertidal populations remained near the edges of the tidal flats at low water; therefore it is unlikely that - even at low water - intertidal and sub- littoral populations would mix. Seasonal migration movements of 0-group plaice have been studied by Zijlstra et al. (1982). They studied intertidal 0-group plaice populations for a number of years and concluded that up until autumn, migration movements were almost absent. Seasonal migration started from October onwards; therefore the period over which growth has been calculated seems to be correct. In this way the sampling programme appears to fulfil the requirements listed by Miller et al. (1992) for designing an optimal sampling programme.

The other aspect concerns the growth estimates, which are based on the mean-length calculations. In the German Wadden Sea, length-frequency distributions of 0 -group plaice appear to be skewed, and therefore in these areas median instead of mean length is calculated (Berghahn 1987). However, in this study the length-frequency distributions of 0 -group plaice were not significantly different from normal distributions, permitting the use of mean-length estimates. In previous research, normally distributed size-frequency distributions of 0 -group plaice were found as well (de Vlas 1979, Zijlstra et al. 1982, van der Veer 1986). Net efficiency will have a strong effect on the sizefrequency distributions and consequently on the meanlength estimates from 1 June to 1 October. During this periad, length of 0-group plaice increased from about 4 to $10 \mathrm{~cm}$. Over this size range the efficiency of the $2 \mathrm{~m}$ beam trawl used in the intertidal is high (Kuipers 1975), between about 70 and $100 \%$. The efficiency of the $3 \mathrm{~m}$ beam trawl for 0 -group plaice used in the sublittoral is also known (Bergman et al. 1989). This means that the size-frequency distributions are not biased by size-selective net efficiency. Therefore, observed increases in mean length can really be considered to reflect growth differences between the various areas.

The aim of the present study was to study growth of 0-group plaice simultaneously with all the important factors such as density, food abundance and avail-

Table 4. Statistical evaluation of influences of plaice density, food abundance and type of area (intertidal versus sublittoral) on growth of 0 -group plaice in the western Wadden Sea, according to general linear model. Dependent variable: growth; $\mathrm{n}=12$; multiple $R=0.938$; squared multiple $R=0.88$; adjusted squared multiple $R=0.834$; standard error of estimate $=3.995$

\begin{tabular}{|c|c|c|c|c|c|c|}
\hline Variable & Coefficient & SE & Std coef. & Tolerance & $t$ & $p(2-t a i l)$ \\
\hline Constant & 59.310 & 3.679 & 0.000 & & 16.123 & 0.000 \\
\hline Plaice density & -0.005 & 0.007 & -0.135 & 0.389 & -0.685 & 0.512 \\
\hline Food abundance & 0.385 & 0.117 & 0.655 & 0.380 & 3.292 & 0.011 \\
\hline Area & 16.417 & 2.390 & -0.861 & 0.958 & -6.869 & 0.000 \\
\hline \multicolumn{7}{|c|}{ Analysis of variance } \\
\hline Source & SS & df & \multicolumn{2}{|c|}{ MS } & $F$ & $\mathrm{p}$ \\
\hline Regression & 932.979 & 3 & \multicolumn{2}{|c|}{310.993} & 19.485 & 0.000 \\
\hline Residual & 127.687 & 8 & \multicolumn{2}{|c|}{15.961} & & \\
\hline
\end{tabular}


ability, and water temperature. Densities of plaice were estimated from catches by small beam-trawls at high water after correction for net efficiency. According to Kuipers (1975), this will result in accurate estimates of actual densities. Moreover, the food abundance is based on actual data on macrozoobenthos. A major part of the food consumption of 0 -group plaice consists of regenerating body parts, especially siphon tips of bivalves and tail tips of lugworms (de Vlas 1979). For this reason food abundance is not expressed in numerical densities but the differences between areas are illustrated by the AFDW of the macrozoobenthic community at the various stations, following de Vlas (1979). The experimental protocol was insufficient to detect differences in water temperature between stations, due to the low frequency of observation. For this reason water temperature has been omitted from the analysis.

\section{‘Maximum growth/optimal food condition' hypothesis}

The MG/OFC hypothesis predicts that (1) growth is not food limited and only dependent on prevailing water temperature, and that (2) there is no intraspecific competition for food, which means no negatively density-dependent growth.

No differences in water temperature were found. According to the predictions of the MG/OFC hypothesis, this would mean a similar growth between 1 June and 1 October in all areas. The results of the growth analysis falsify this prediction. Growth was different between stations and it was positively related with food abundance, in both the intertidal and the sublittoral. This indicates that in a number of areas growth is not maximal and depends on food abundance and food composition. Stomach-content analysis of 0 -group plaice at high water did not reveal any difference in composition in relation to food abundance in the intertidal and sublittoral areas. The prey items were always similar. A comparison of the prey items of o-group plaice foraging in the intertidal with those in the sublittoral also showed a high similarity. The only difference found was the absence of tail tips of Arenicola marina in the stomachs of plaice in the sublittoral. This was to be expected, because of the almost complete absence of this lugworm in the sublittoral benthos (Dekker 1989). Despite the similarities, higher growth rates were found in the intertidal, although these animals have to swim to and from the intertidal with the tides. Moreover, they also have less time available for feeding: only when the tidal flats are submerged. There are no indications that the observed differences in growth rate might result from consistent differences in water temperature. The Wadden Sea is a. well-mixed estuary and, although in summer the water in the intertidal may be warmed up during the day, the reverse will be true at night. The higher growth rates of the intertidal 0-group plaice suggest that the shorter feeding period and additional energy loss by longdistance swimming is more than compensated for. Stomach content analysis shows that the presence of lugworms in the intertidal is important.

Gibson (1980) observed a change in behaviour of wild plaice when they encounter lugworms as prey. They become less active in terms of swimming, and consequently spend less effort and energy in collecting tail tips of lugworms compared to other prey items. Studies on food intake of juvenile plaice in the intertidal of the Wadden Sea by Kuipers (1977) and de Vlas (1979) revealed that up to $20 \%$ of the energy uptake of plaice consists of tail tips of the lugworm Arenicola marina. This might explain the observed differences in growth rate between intertidal and sublittoral populations. Tail tips of $A$. marina are by far the largest prey items of 0 -group plaice, with an energy content of 4 to $5 \mathrm{mg}$ compared with about $1 \mathrm{mg}$ for siphons, another important food source (de Vlas 1979). If the differences in growth rate between intertidal and sublittoral areas can be attributed to the presence of $A$. marina, one would also expect a positive relationship between abundance of $A$. marina at the intertidal stations and growth of 0 -group plaice. The field data support this view (Fig. 9).

One can conclude that food composition and quality have a direct effect on growth of 0 -group plaice. In juvenile animals growth is directly related with food intake. Food composition and quality have a direct effect on the energy-consuming activities (swimming,

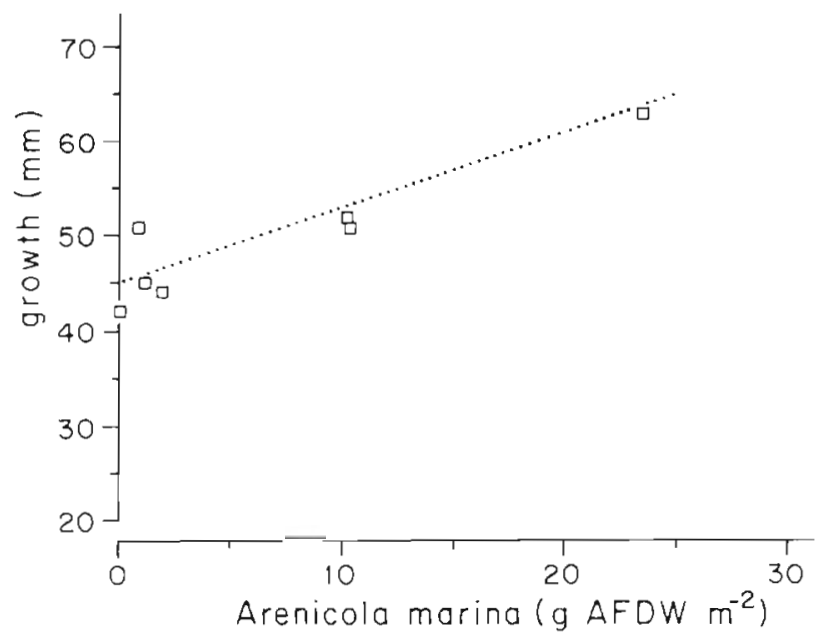

Fig. 9. Pleuronectes platessa. Relationship between growth of 0 -group plaice $(\mathrm{mm})$ and density of the lugworm Arenicola marina (nos. $\mathrm{m}^{-2}$ ) during the growth period 1 June to 1 October in the western Wadden Sea in the intertidal 
searching and biting), and also on the total amount of energy consumed in the form of prey items. The balance between these 2 aspects determines the ultimate 'scope for growth'.

The relationship between growth and food abundance does not necessarily entail intraspecific competition for food. There was no significant negative relationship between growth and plaice density. This does not mean that such a relationship does not exist, but within this experimental framework it could not be found and its effect seems marginal compared with the impact of food. The prediction of the MG/OFC hypothesis that density of 0-group plaice has no impact on growth therefore was not falsified and this supports previous research in the same area (Zijlstra et al. 1982, van der Veer 1986, van der Veer et al. 1990, Karakiri et al. 1991).

The relationship between growth and food abundance as found for both the intertidal and the sublittoral supports the results of Karakiri et al. (1989) for the German Wadden Sea. Macrozoobenthic food abundance and composition determine the growth rate of plaice, whereby in some areas the maximum possible growth rate at that water temperature can be achieved. Karakiri et al. (1989) attribute these differences in growth to food limitation. However, the present study shows that even under these conditions there might have been no density-dependent growth. The results of the present study are also in accordance with the observations of changes in somatic growth of female North Sea plaice by Rijnsdorp \& van Leeuwen (1992). Back-calculations based on otoliths suggest an increased growth of juvenile plaice starting in the 1950s, probably related to an increase in food in the coastal waters. This study shows that this might have been the case without any density-dependent component. Food limitation and hence density-dependent growth are also suggested by Shaw \& Jenkins (1992) for juvenile flounder Rhombosolea tapirina in a subtropical estuary. However, their data do not support this view. Growth was not related with flounder density and their study was restricted to only 1 yr of observation. Actually growth was higher in an area with a higher flounder density, suggesting a situation like in this study: differences in growth are determined by food abundance and composition, without any density-dependent component

This complex system at least illustrates that one should be very careful in drawing conclusions about food limitations. Conclusions about density-dependent growth can only be drawn if growth of 0-group flatfish is followed over a number of years at different densities. A comparison between areas should also include information about food composition and abundance, otherwise the MG/OFC hypothesis cannot be tested.
The present knowledge of the Wadden Sea system indicates that differences in growth rate are the result of differences in food abundance and quality, but not the result of food-limited, or in other words densitydependent growth (which assumes a negative relationship between plaice density and growth)

In a review of the 'Optimal Foraging Theory' (OFT) in the marine environment (Hughes 1980), one of the main premises in relation to choice of habitats for foraging, searching methods and prey choice is the 'Energy Maximization Premise' (EMP). In short, the EMP assumes that predators will always try to maximize the net rate of energy gain. The growth characteristics of 0 -group plaice in the western Wadden Sea seem to support this view. The relationship between presence and abundance of Arenicola marina and growth suggests that 0 -group plaice select for this large prey item. 0-group plaice populations in the sublittoral lack this food source and consequently show a lower growth rate. These subpopulations settle in the sublittoral and never exhibit tidal migrations. Intertidal populations settle on the tidal flats (van der Veer \& Bergman 1986) where they find the lugworms and other prey. Therefore, tidal migrations are not a migration onto the flats at high water, but an escape from the flats at low water, as already pointed out by van der Veer \& Bergman (1986).

The present data set does not allow an analysis of prey preference in relation to prey density. However, o-group plaice seem a suitable study object for such a more detailed analysis.

Acknowledgements. Thanks are due to the crew of RV 'Navicula' and to M. J. N. Bergman, J. P. van Dessel and A. Stam for assistance during sampling. J. van der Meer advised on statistical analysis of the data. Three reviewers critically evaluated an earlier draft of the manuscript. Their useful comments are appreciated.

\section{LITERATURE CITED}

Berghahn, R. (1987). Effects of tidal migration on growth of 0 group plaice (Pleuronectes platessa L.) in the North Frisian Wadden Sea. Meeresforsch. 31. 209-226

Bergman, M. J. N., van der Veer, H. W., Stam, A., Zuidema, D (1989). Transport mechanisms of larval plaice (Pleuronectes platessa L.) from the coastal zone into the Wadden Sea nursery area. Rapp. P.-v. Réun. Cons. int. Explor. Mer 191. 43-49

Bergman, M. J. N., van der Veer, H. W., Zijlstrā, J. J. (1988). Plaice nurseries: effects on recruitment. J. Fish Biol. 33 (Suppl. A): 201-218

Beukema, J. J. (1989). Long-term changes in macrozoobenthic abundance on the tidal flats of the western part of the Dutch Wadden Sea. Helgoländer Meeresunters. 43: 405-415

Beverton, R. J. H. (1984). Dynamics of single species. In May, R. M. (ed.) Exploitation of marine communities Springer-Verlag, Berlin, p. 13-58 
Dapper, R. (1978). De Balgzand scholgegevens 1975, 1976 , 1977. Neth. J. Sea Res. Intern. Rep. 1978-12, p. 1-53

Dekker, R. (1989). The macrozoobenthos of the subtidal western Dutch Wadden Sea. I. Biomass and species nchness. Neth. J. Sea Res. 23: 57-68

de Vlas, J. (1979). Annual food intake by plaice and flounder in a tidal flat area in the Dutch Wadden Sea, with special reference to consumption of regenerating parts of macrobenthic prey. Neth. J. Sea Res. 13: 117-153

Edwards, R., Steele, J. H. (1968). The ecology of 0-group plaice and common dab at Loch Ewe. I. Population and food. J. exp. mar. Biol. Ecol. 2: 215-238

Gibson, R. N. (1980). A quantitative description of the behaviour of wild juvenile plaice (Pleuronectes platessa L.). Anim. Behav. 28: 1202-1216

Hughes, R. N. (1980). Optimal foraging theory in the marine context. In: Barnes, M. (ed.) Oceanogr. mar. Biol. A. Rev. 18: $423-481$

Karakiri, M., Berghahn, R., van der Veer, H. W. (1991). Variations in settlement and growth of 0 -group plaice (Pleuronectes platessa L.) in the Dutch Wadden Sea as determined by otolith microstructure analysis. Neth. J. Sea Res. 27: 345-351

Karakiri, M., Berghahn, R., von Westernhagen, H. (1989). Growth differences in 0-group plaice Pleuronectes platessa as revealed by otolith microstructure analysis. Mar. Ecol. Prog. Ser. 55: 15-22

Kuipers, B. R. (1973). On the tidal migration of young plaice (Pleuronectes platessa L.) in the Wadden Sea. Neth. J. Sea Res. 6: 376-388

Kuipers, B. R. (1975). On the efficiency of a two meter beam trawl in juvenile plaice (Pleuronectes platessa L.). Neth. J. Sea Res. 9: 69-85

Kuipers, B. R. (1977). On the ecology of juvenile plaice on a tidal flat in the Wadden Sea. Neth. J Sea Res. 11: $56-91$

Miller, J. M., MacCurrin, B., van der Veer, H. W. (1992). Growth and mortality in juvenile flatfish; the design of optimal sampling programmes. Neth. J. Sea Res. 29: 93-96

Reichert, M. J. M., van der Veer, H. W. (1.991). Settlement, abundance, growth and mortality of juvenile flatfish in a

This article was submitted to the editor subtropical tidal estuary (Georgia, U.S.A.). Neth. J. Sea Res. 27: 375-391

Rijnsdorp, A. D., van Leeuwen, P. I. (1992). Density-dependent and density-independent changes in somatic growth of female plaice Pleuronectes platessa between 1930 and 1985 as revealed by back-calculation of otoliths. Mar. Ecol. Prog. Ser. 88: $19-32$

Shaw, M., Jenkins, G. P. (1992). Spatial variation in feeding, prey distribution and food limitation of juvenile flounder Rhombosolea tapirina Günther. J. exp. mar. Biol. Ecol. 165: 1-21

Steele, J. H., Edwards, R. R. C. (1970). The ecology of 0-group plaice and common dabs in Loch Ewe. IV. Dynamics of the plaice and dab populations. J. exp. mar. Biol. Ecol. 4: $174-187$

van der Veer, H. W. (1986). Immigration, settlement and density-dependent mortality of a larval and early postlarval 0-group plaice (Pleuronectes platessa) population in the western Dutch Wadden Sea. Mar. Ecol. Prog. Ser. 29: $223-236$

van der Veer, H. W., Bergman, M. J. N., Dapper, R., Witte, J. IJ. (1991). Population dynamics of an intertidal 0-group flounder Platichthys flesus population in the western Dutch Wadden Sea. Mar. Ecol. Prog. Ser. 73: 141-148

van der Veer, H. W., Bergman, M. J. N. (1986). Development of tidally related behaviour of a newly settled 0-group plaice (Pleuronestes platessa L.) population in the western Wadden Sea. Mar. Ecol. Prog. Ser 31: 121-129

van der Veer, H. W., Pihl, L., Bergman, M. J. N. (1990). Recruitment mechanisms in North Sea plaice Pleuronectes platessa. Mar. Ecol. Prog. Ser. 64: 1-12

Wilkinson, L. (1989). SYSTAT: the system for statistics SYSTAT Inc., Evanston, IL

Zijlstra, J. J. (1972). On the importance of the Waddensea as a nursery area in relation to the conservation of the southern North Sea fishery resources. Symp. zool. Soc. London 29 : $233-258$

Zijlstra, J. J., Dapper, R., Witte, J. IJ. (1982). Settlement, growth and mortality of post-larval plaice (Pleuronectes platessa L.) in the western Wadden Sea. Neth. J. Sea Res. 15: $250-272$

Manuscript first received: January 25, 1993

Revised version accepted: August 4, 1993 